\title{
IMPLIKASI PUTUSAN HAK UJI MATERIL DI MAHKAMAH AGUNG TERHADAP LEGALITAS PIMPINAN DEWAN PERWAKILAN DAERAH REPUBLIK INDONESIA
}

(Implication of the Decision on Material Review by the Supreme Court to the Legality of Chairman of the Regional Representative Council of the Republic of Indonesia)

\author{
Andryan \\ Fakultas Hukum Universitas Muhammadiyah Sumatera Utara \\ Jalan Kapt. Mochtar Basri No.3 Medan, 20238 \\ Telp. (061) 6623301 Fax. (061) 6625474 \\ e-mail: andryan@umsu.ac.id
}

Tulisan Diterima: 09-08-2018; Direvisi: 05-08-2018: Disetujui Diterbitkan: 06-09-2018

DOI: http://dx.doi.org/10.30641/dejure.2018.V18.367-380

\begin{abstract}
The Supreme Court has the power vested on it under Article 24A Clause (1) 1945' Constitution to conduct material test on the regulations issued under such laws. This article describes the issue of the Legality of the Chairman of the Regional Representative Council of the Republic of Indonesia following the Decision on Material Review by the Supreme Court No. 20P/HUM/2017 on the Regulation of the Regional Representative Council No. 1 of 2017 regarding Code of Conduct. Theoretically, this research is expected to contribute ideas to the development of the rights of material review and the nature of the decision. This research is a legal research using juridical normative method. The approaches used in this research include the statute approach, conceptual approach and case approach. While the conclusion of this research, the implication of the appointment of the Chairman of the Regional Representative Council following the Decision on Material Review by the Supreme Court No. 20P/HUM/2017, is that legally the election of "new' chairman for a term of office of 2.5 year conducted based on the revoked regulation can be classified as an illegal move or act against the law. The consequences is, the action should not be recognized as legal by the law and should be declared null and void by the operation of the laws.
\end{abstract}

Keywords: Implication of Decision, Material Review, Legality

\begin{abstract}
ABSTRAK
Mahkamah Agung mempunyai kewenangan yang ditegaskan dalam Pasal 24A Ayat (1) UUD 1945, yakni menguji peraturan perundang-undangan di bawah undang-undang. Tulisan ini menguraikan permasalahan terhadap legalitas Pimpinan Dewan Perwakilan Daerah Republik Indonesia pasca Putusan Hak Uji Materil Mahkamah Agung Nomor 20P/HUM/2017 terhadap Peraturan Dewan Perwakilan Daerah Nomor 1 Tahun 2017 tentang Tata Tertib. Dalam tataran teoritis, penelitian ini diharapkan dapat memberikan sumbangan pemikiran terhadap perkembangan Hak Uji Materil terhadap serta sifat putusannya. Penelitian ini merupakan penelitian hukum dengan jenis penelitian yuridis normatif dan menggunakan jenis penelitian yuridis normatif. Pendekatan masalah yang digunakan dalam penelitian ini meliputi pendekatan undang-undang (statute approach), pendekatan konseptual (conceptual approach) dan pendekatan kasus (case approach). Adapun kesimpulan dalam penelitian ini, yakni Implikasi Pengangkatan Pimpinan Dewan Perwakilan Daerah Pasca Putusan Hak Uji Materil Mahkamah Agung Nomor 20P/HUM/2017, bahwa secara hukum, tindakan pemilihan pim-pinan "baru" versi jabatan 2,5 tahun itu tetap dilakukan berdasarkan peraturan yang telah dibatalkan, maka tindakan tersebut dapat disebut sebagai tindakan ilegal atau tindakan yang berlawanan dengan hukum. Konsekuensinya, tindakan tersebut menjadi tidak sah secara hukum dan dapat dinyatakan ba-tal demi hukum.
\end{abstract}

Kata Kunci: Implikasi Putusan, Hak Uji Materi, Legalitas 


\section{PENDAHULUAN}

Indonesia sebagai suatu negara yang diidealkan dan dicita-citakan oleh the founding father se-bagai negara dengan konsep negara hukum (Rechtsstaat/The Rule of Law). Hal ini sebagaimana yang telah ditegaskan dalam Pasal 1 Ayat (3) Undang-Undang Dasar Negara Republik IndonesiaTahun 1945(UUD 1945), bahwa "Negara Indonesia adalah negara hukum. Sebagai negara hukum, maka hukum merupakan satu sistem yang di dalamnya terdapat (1) elemen kelembagaan (elemen insti-tusional; (2) elemen kaidah aturan (elemen instrumental); dan (3) elemen perilaku para subjek hukum yang menyandang hak dan kewajiban yang ditentukan oleh norma aturan (elemen subjektif dan kul-tural). Adapun ketiga elemen sistem hukum, mencakup (a) kegiatan pembuatan hukum (law making), (b) kegiatan pelaksanaan hukum atau penerapan hukum (law administrating), dan (c) kegiatan peradi-lan atas pelanggaran hukum (law adjudicating) atau yang biasa disebut dengan penegakkan hukum dalam arti sempit (law enforcement) (Asshiddiqie (1), 2009: 3).

Terdapat tujuh faktor penghambat penegakan hukum di Indonesia, ketujuh faktor tersebut yai-tu 1. Lemahnya political will dan political action para pemimpinnegaraini,untukmenjadihukumse-bagai panglima dalam penyelenggaraan pemerintahan. Dengan kata lain, supremasi hukum masih sebatas retorika dan jargon politik yang didengungdengungkan pada saat kampanye; 2. Peraturan pe-rundang-undangan yang ada saat ini masih lebih merefeksikan kepentingan politik penguasa ketim-bang kepentingan rakyat; 3. Rendahnya integritas moral, kredibilitas, profesionalitas dan kesadaran hukum aparat penegak hukum (Hakim, Jaksa, Polisi dan Advokat) dalam menegakkan hukum; 4. Min-imnya sarana dan prasana serta fasilitas yang mendukung kelancaran proses penegakan hukum; 5. Tingkat kesadaran dan budaya hukum masyarakat yang masih rendah serta kurang respek terhadap hukum; 6. Paradigma penegakan hukum masih positivis-legalistis yang lebih mengutamakan tercapainya keadilan formal (formal justice) daripada keadilan substansial (substantial justice); 7. Ke-bijakan (policy) yang diambil oleh para pihak terkait (stakeholders) dalam mengatasi persoalan pene-gakan hukum masih bersifat parsial, tambal sulam, tidak komprehensif dan tersistematis. (Jazuli (2016: 192-193).

Berdasarkan studi ilmu hukum tiga asas sebagaimana dimaksud merupakan pilar penting da-lam memahami konstruksi hukum perundangundangan di Indonesia secara detail dapat dijelaskan bahwa: (Sihombing, 2016: 100).

a) Asas lex superior de rogat lex inferior, peraturan yang lebih tinggi akan mengesampingkan peraturan yang lebih rendah apabila mengatur substansi yang sama dan bertentangan.

b) Asas lex specialist derogat lex generalis, peraturan yang lebih khusus akan mengesampingkan peraturan yang umum apabila mengatur substansi yang sama dan bertentangan.

c) Asas lex posterior de rogat lex priori, peraturan yang baru akan mengesampingkan peraturan yang lama.

Amandemen UUD 1945 pada periode 19992002, telah banyak membawa perubahan dalam perkembangan sistem hukum, salah satunya dengan penerapan pengujian di bidang perundangundangan. Dalam UUD 1945, telah menentukan kebijakan dasar bahwa kekuasaan kehakiman diberi hak menguji (toetsingsrecht) peraturan perundang-undangan. Mahkamah Konstitusi (MK) berwenang menguji undang-undang terhadap undang-undang dasar. Sementara itu, Mahkamah Agung (MA) ber-dasarkan undangundang berwenang menguji peraturan perundangundangan di bawah undang-undang. (Soebechi, 2016: vi).

Pada Pasal 20 ayat (2) huruf (b) UndangUndang No. 48 Tahun 2009 tentang Kekuasaan Ke-hakiman, menyatakan Mahkamah Agung berwenang menguji peraturan perundangundangan di bawah undang-undang terhadap undang-undang. Selanjutnya, pada Pasal 9 Ayat (2) Undang-Undang Nomor 12 Tahun 2011 tentang Pembentukan Peraturan PerundangUndangan (P3) yang menyatakan, dalam hal suatu peraturan perundang-undangan di bawah undangundang diduga bertentangan dengan undangundang pengujiannya dilakukan oleh Mahkamah Agung. Ketentuan hak menguji Mahkamah Agung sebelumnya diatur dalam Undang-Undang No.14 Tahun 1970 tentang Ketentuan Pokok Kekuasaan Kehakiman, dimana pada Pasal 26 menyatakan, 
bahwa (1) Mahkamah Agung berwenang untuk menyatakan tidak sah semua perundangundangan dari tingkat yang lebih rendah dari undang-undang atas alasan bertentangan dengan peraturan perundang-undangan yang lebih tinggi;

(2) Putusan tentang tidak sahnya peraturan perundang-undangan tersebut dapat diambil berhubung dengan pemeriksaan dalam tingkat kasasi.

Dalam ketentuan Pasal 8 Ayat (1) UU No.12 Tahun 2011 tentang Pembentukan Peraturan Perundang-Undangan (UU P3), menegaskan adapun jenis peraturan perundang-undangan selain se-bagaimana dimaksud dalam Pasal 7 Ayat (1) tentang hierarki peraturan perundangundangan, juga mencakup peraturan yang ditetapkan oleh lembaga negara, diantaranya adalah Dewan Perwakilan Daerah, Mahkamah Agung, Mahkamah Konstitusi, Badan Pemeriksa Keuangan, Komisi Yudisial, Bank Indonesia, Menteri, badan, lembaga, atau komisi yang setingkat yang dibentuk dengan Undang-Undang atau Pemerintah atas perintah Undang-Undang, Dewan Perwakilan Rakyat Daerah Provinsi, Gubernur, Dewan Perwakilan Rakyat Daerah Kabupaten/Kota, Bupati/Walikota, Kepala Desa atau yang setingkat.

Sebagaimana yang telah diatur dalam ketentuan UU No.12 Tahun 2011, Mahkamah Agung yang berwenang menguji peraturan perundang-undangan di bawah undang-undang, juga terhadap per-aturan yang dibuat oleh lembaga-lembaga negara, salah satunya Peraturan Dewan Perwakilan Daerah (DPD). Terkait dengan proses pengujian Peraturan Tata Tertib (Tatib) DPD, Putusan Mahkamah Agung Nomor 38P/HUM/2016 telah membatalkan Peraturan DPD Nomor 1 Tahun 2016. Peraturan tersebut dinyatakan bertentangan dengan UU Nomor 17 Tahun 2014 Tentang MPR, DPR, DPD, dan DPRD (UU MD3). Sedangkan, Putusan Mahkamah Agung Nomor 20P/HUM/2017, merupakan putusan yang membatalkan Peraturan DPD-RI Nomor 1 Tahun 2017 Tentang Tata Tertib. Di dalam putusannya, Peraturan DPD-RI Nomor 1 Tahun 2017 dinyatakan bertentangan dengan UU Nomor 12 Tahun 2011 tentang Pembentukan Peraturan Perundang-undangan. Adapun basis persoalan di dalam kedua peraturan DPD-RI tersebut sama, yakni pengaturan masa jabatan Ketua DPD-RI selama 2,5 tahun.
Pasca putusan Hak Uji Materil Mahkamah Agung yang menganulir Tatib DPD, menimbulkan kisruh secara internal di kelembagaan DPD menyangkut pemilihan pimpinan DPD. Hal ini ditambah dengan keterlibatan MA secara kelembagaan melalui Wakil Ketua MA dalam proses pelantikan terhadap Pimpinan DPD terpilih. Di satu pihak MA membatalkan ketentuan dasar dalam proses pemili-han pimpinan DPD, tetapi di lain pihak MA justru "merestui" pengangkatan pimpinan DPD. Dengan demikian, apabila dikaitkan dengan sifat putusan MA yang tidak menentukan putusan serta-merta, menjadi problematika pengangkatan pimpinan DPD terhadap legalitas secara hukum. Maka, dalam tulisan ini akan diuraikan "Implikasi Sifat Putusan Hak Uji Materil Mahkamah Agung Terhadap Legali-tas Pemilihan Pimpinan DPD”. Dengan demikian, dalam penelitian ini akan diuraikan permasalahan, pada bagian pertama akan menggambarkan bagaimana konsep pengujian perundang-undangan, dilanjutkan pada permasalahan kedua terhadap sifat putusan Mahkamah Agung dalam Hak Uji Materil sebagaimana yang ditegaskan dalam konstitusi terhadap kewenangan Mahkamah Agung. Selanjutnya dalam permasalahan ketiga, penulis akan mengupas analisis putusan Mahkamah Agung terhadap legal-itas pimpinan Dewan Perwakilan Daerah pasca putusan Hak Uji Materil Mahkamah Agung Nomor 20P/HUM/2017.

\section{METODE PENELITIAN}

Penelitian ini menggunakan jenis penelitian yuridis normatif. Pendekatan masalah yang digunakan dalam penelitian inimeliputi pendekatan undang-undang (statute approach), pendekatan konseptual (conceptual approach) dan pendekatan kasus (case approach). Penelitian ini merupakan penelitian deduktif yang menggambarkan peristiwa hukum dan akibat hukum dikaitkan dengan Putusan Mahkamah Agung Nomor 20P/ HUM/2017 terhadap Peraturan Dewan Perwakilan Daerah Nomor 1 Tahun 2017 tentang Tata Tertib. Data yang diperoleh dikumpulkan dan di analisis secara kualitatif dengan model deskriptifanalitis. Sehingga hasilnya dapat diuraikan secara komprehensif dan sistematis mengenai dasar pertimbangan hakim dalam putusannya. 


\section{PEMBAHASAN DAN ANALISIS}

\section{A. Konsep Pengujian Peraturan Perundang- Undangan}

Negara hukum diistilahkan dengan nama rechstaats atau the rule of law. Di Indonesia, pendirian negara sejak semula telah dicita-citakan oleh the founding father sebagai suatu negara hukum. Dalam rangka perubahan ketiga UUD 1945 Pasal 1 ayat (3) ditegaskan bahwa "Negara In-donesa adalah Negara Hukum". Meskipun secara eksplisit telah tertuang dalam konstitusi sebagai negara yang berdasarkan atas hukum, namun cetak biru dan desain makro penjabaran ide negara hukum belum secara tegas dirumuskan secara komprehensif.

Ide negara hukum sesungguhnya telah lama dikembangkan oleh para filsuf dari zaman Yunani Kuno, Plato, dalam bukunya "the Statesman" dan "the Law", menyatakan bahwa negara hukum merupakan bentuk paling baik kedua (the second best) guna mencegah kemerosotan kekuasaan seseorang adalah pemerintahan oleh hukum. Konsep negara hukum modern di Eropa Kontinental dikembangkan dengan menggunakan istilah Jerman yaitu rechtsstaat" antara lain oleh Immanuel Kant, Paul Laband, Julius Stahl, Fichte, dan lain-lain. Sedangkan tradisi Anglo Amerika, konsep negara hukum dikembangkan dengan sebutan "the Rule of Law" yang dipelopori oleh A.V.Dicey (Asshiddi-qie (2), 2005: 152).

Dalam hal itu, ide negara hukum, selain terkait dengan konsep "rechtsstaat" dan "the rule of law", juga terkait dengan konsep "nomocracy" yang berasal dari perkataan "nomos" dan "cratos". Perkataan nomokrasi itu dapat dibandingkan dengan "demos" dan "cratos" atau "kratien" dalam demokrasi. Nomos berarti norma, sedangkan cratos adalah kekuasaan. Menurut Julius Stahl, konsep Negara Hukum yang disebutkannya dengan istilah "rechtsstaat" itu mencakup empat elemen penting, yaitu: (Asshiddiqie (1), 2009: 189-199)

1. Perlindungan hak asasi manusia;

2. Pembagian kekuasaan;

3. Pemerintahan berdasarkan undang-undang;

4. Peradilan tata usaha negara.

Sedangkan A.V.Dicey, menguraikan adanya tiga ciri penting dalam setiap Negara Hukum yang disebutkannya dengan istilah "The Rule of Law",
“The Rule of Law”, yaitu: (Asshiddiqie (2), 2009: 199)

1. Supremacy of Law;

2. Equality Before The Law;

3. Due Process of Law.

Keempat prinsip "rechtsstaat" yang dikembangkan oleh Julius Stahl dapat digabungkan dengan ketiga prinsip "Rule of Law" yang dikembamgkan oleh A.V.Dicey untuk mencapai ciri-ciri Negara Hukum modern. Selain daripada itu, oleh "The International Commission of Jurist", prinsip-prinsip Negara Hukum juga meliputi, (1) negara harus tunduk pada hukum; (2) pemerintah menghor-mati hak-hak individu dan (3) peradilan bebas dan tidak memihak.

Profesor Utrecht membedakan antara Negara hukum formil atau Negara hukum klasik, dan negara hukum materiel atau Negara hukum modern (Utrecht, 1962: 9). Negara hukum formil menyangkut pengertian hukum yang bersifat formil dan sempit, yaitu dalam arti peraturan perundang-undangan tertulis. Sedangkan yang kedua, yaitu Negara Hukum Materiel yang lebih mutakhir men-cakup pula pengertian keadilan di dalamnya. Karena itu, Wolfgang Friedman dalam bukunya 'Law in a Changing Society' membedakan antara 'rule of law' dalam arti formil yaitu dalam arti 'organized public power', dan 'rule of law' dalam arti materiel yaitu 'the rule of just law'.

Pembedaan ini dimaksudkan untuk menegaskan bahwa dalam konsepsi negara hukum itu, keadilan tidak serta-merta akan terwujud secara substantif, terutama karena pengertian orang mengenai hukum itu sendiri dapat dipengaruhi oleh aliran pengertian hukum formil dan dapat pula dipengaruhi oleh aliran pikiran hukum materiel. Jika hukum dipahami secara kaku dan sempit dalam arti peraturan perundang-undangan semata, niscaya pengertian negara hukum yang dikembangkan juga bersifat sempit dan terbatas serta belum tentu menjamin keadilan substantive. Karena itu, di samping istilah 'the rule of law' oleh Friedman juga dikembangikan istilah 'the rule of just law' untuk memastikan bahwa dalam pengertian kita tentang 'the rule of law' tercakup pengertian keadilan yang lebih esensiel daripada sekedar memfungsikan peraturan perundangundangan dalam arti sempit. Kalaupun istilah yang digunakan tetap 'the rule of law', pengertian 
yang bersifat luas itulah yang diharapkan dicakup dalam istilah 'the rule of law' yang digunakan untuk menyebut konsepsi Negara hukum di zaman sekarang (Utrecht, 1962: 9).

Konsep mengenai wewenang menguji untuk menjaga kesucian konstitusi oleh lembaga yudisial ini dapat melihat beberapa putusan yang dikeluarkan oleh Mahkamah Agung di Amerika Serikat. Di dalam memberikan putusan, MA dapat berdasarkan pada peraturan yang dibuat oleh Kongres maupun pada doktrin. Sebagian besar kasus yang ditangani MA merupakan hasil interpretasi hukum dalam menentukan apakah suatu peraturan atau pejabat berjalan sesuai dengan konstitusi atau tidak. Wewenang MA ini tidak disebutkan secara khusus dalam konstitusi AS, akan tetapi didasarkan pada doktrin yang disimpulkan oleh MA berdasarkan naskah konstitusi dan telah dinyatakan secara gamblang dalam kasus penting yaitu Marbury vs. Madison tahun 1803. Dalam putusannya MA dengan hakim Marshall menyatakan bahwa "...tindakan legislatif yang bertentangan dengan Konstitusi bukanlah Hukum...", dan lebih lanjut menambahkan bahwa "adalah wewenang dan tugas dan wewenang dari lembaga peradilan untuk menyatakan apakah hukum itu". Atas dasar inilah, maka MA mempunyai wewenang untuk melakukan pengujian (judicial review) terhadap undangundang yang dianggap bertentangan dengan konstitusi AS (Schroeder, 2000: 96).

Tradisi AS inilah yang kemudian menjadi tonggak bagi lahirnya ajaran supremasi konstitusional dalam pengujian peraturan perundang-undangan. Menurut Smith Baily (Inggris), bahwa judicial review didirikan atas dasar doktrin Ultra Vires (ultra vires doctrin) yang digunakan dalam sistem hukum di Inggris. Berdasarkan doktrin tersebut, M. Yahya Harahap (1997:44), menyatakan bahwa kekuasan yudikatif diberikan hak dan kewenangan, yakni:

a. mengawasi batas kewenangan pemerintah dalam mengeluarkan peraturan perundangundangan (statutory authority) sesuai dengan batas yurisdiksi atau kawasan kekuasaannya.

b. kekuasaan yudikatif diberikan hak, fungsi dan kewenangan untuk melakukan pengawasan terhadap penguasa pusat maupun daerah dan lokal untuk tidak melakukan penyalahgunaan kekuasaan (abuse of power) melampaui batas-batas yurisdiksinya.

c. Apa-apa yang tidak didelegasikan undangundang kepada penguasa, atau membuat peraturan perundang-undangan yang jauh lebih luas dari apa yang telah didelegasikan, harus dinyatakan sebagai tindakan yang tidak berdasar hukum (unlawful), karena dianggap sebagai tindakan yang illegal.

Konsep judicial review berasal dari negaranegara yang menganut prinsip supremasi konstitusi. Istilah judicial review itu sendiri merupakan istilah khas hukum tata negara Amerika Serikat yang artinya wewenang lembaga pengadilan untuk membatalkan setiap tindakan pemerintahan yang berten-tangan dengan konstitusi. Menurut Soepomo, di Belanda tidak dikenal istilah judicial review, mereka hanya mengenal istilah hak menguji (toetsingensrecht). Judicial review merupakan mekanisme pen-gujian peraturan perundang-undangan tertentu oleh hakim. Pengujian itu dilakukan atas suatu ketentuan peraturan perundang-undangan terhadap peraturan perundang-undangan yang lebih tinggi atau ter-hadap konstitusi sebagai hukum tertinggi (MD Mahfud, 2009: 8).

Fatmawati, menyatakan definisi dari judicial review pada comman law system dan hak menguji (toetsingrecht) pada civil law system, terlihat perbedaan pada keduanya, yakni: (Sulaiman, 2017: 105-106).

1. Hak menguji (toetsingrecht) merupakan kewenangan untuk menilai peraturan perundang-undang terhadap UUD, sedangkan judicial review tidak hanya menilai peraturan perundang-undangan tetapi juga administrative action terhadap UUD;

2. Hak menguji (toetsingrecht) terhadap peraturan perundang-undangan tidak hanya dimiliki oleh ha-kim, tetapi juga oleh lembaga negara lain yang diberi kewenangan tersebut berdasarkan peraturan perundangundangan, sedangkan judicial review hanya merupakan kewenangan dari hakim pengadilan dalam kasus konkret di pengadilan.

Dalam praktek, dikenal adanya tiga macam norma hukum yang dapat diuji atau yang biasa disebut sebagai norm control mechanism. Ketiganya sama-sama merupakan bentuk norma hukum se-bagai hasil dari proses pengambilan 
keputusan hukum, yaitu: (i) keputusan normatif yang berisi dan bersifat pengaturan (regeling), (ii) keputusan normatif yang berisi dan bersifat penetapan administratif (beschikking), dan (iii) keputusan normatif yang berisi dan bersifat penghakiman (judgement) yang biasa disebut vonis (Asshiddiqie (3), 2006: 3). Ketiga bentuk norma hukum tersebut di atas sama-sama dapat diuji kebenarannya melalui mekanisme peradilan (justisial) ataupun mekanisme nonjustis-ial. Jika pengujian itu dilakukan oleh lembaga peradilan, maka proses pengujiannya itu disebut sebagai judicial review atau pengujian oleh lembaga judisial atau pengadilan. Akan tetapi, jika pengujian itu dilakukan bukan oleh lembaga peradilan, maka hal itu tidak dapat disebut sebagai judicial review.

Kewenangan Mahkamah Agung dalam melaksanakan Hak Uji Materiil (HUM) pada mulanya didasarkan pada landasan hukum Pasal 24 UUD 1945 sebagaimana telah diamandemen menjadi Pasal 24A UUD 1945. Dalam Pasal 26 UU No. 14 Tahun 1970 tentang Ketentuan Pokok Kekuasaan Keha-kiman; Pasal 11 Ayat (4) Ketetapan MPR No. III/ MPR/1978 tentang Kedudukan dan Hubungan Ta-takerja Lembaga Tertinggi Negara dengan/atau Antar Lembaga Tinggi Negara; Pasal 31 UU No. 14 Ta-hun 1985 tentang Mahkamah Agung. Pasal 11 UU No. 4 Tahun 2004 tentang Kekuasaan Kehakiman Pasal 20 UU No 48 Tahun 2009 tentang Kekuasaan Kehakiman. Menurut Paulus Effendi Lotulung, bahwa alasan prosedur HUM dibuat dalam bentuk hukum PERMA didasarkan pada pertimbangan ke-tentuan Undang-undang yang memberikan kewenangan HUM tersebut hanya bersifat singkat saja tanpa mengatur tentang tata cara atau prosedur.

Mengenai judicil review, dalam undangundang asalnya semua pengadilan diperbolehkan menguji peraturan perundang-undangan di bawah undang-undang dan menyatakan peraturan yang diuji tersebut tidak mengikat karena bertentangan dengan undang yang lebih tinggi. Pada tahun 1967, dalam beberapa perkara yang menonjol, pengadilan-pengadilan di tingkat bawah mulai secara eksplisit membatalkan peraturan (semi) perundang-undangan karena diduga bertentangan dengan peraturan yang lebih tinggi. Meski begitu, UU No.14 tahun 1970 Pasal 26 Ayat (1), justru membatasi kewenangan menguji materil pada Mahkamah Agung saja dan tidak mengizinkan pengadilan-pengadilan di tingkat bawah mempertanyakan keabsahan instrumen legislatif manapun (Pompe, 2012: 353).

Judicial Review atau Hak Uji Materiil (disingkat HUM), pada prinsipnya adalah suatu hak atau kewenangan yang dimiliki oleh lembaga Yudikatif untuk melakukan pengujian mengenai sah atau tid-aknya suatu peraturan perundangundangan terhadap peraturan perundangundangan yang tingkatnya lebih tinggi. Hak uji materiil di Indonesia dapat digolongkan menjadi dua macam, yaitu:

1. Hak Uji Materiil atas Undang-Undang terhadap Undang-Undang Dasar, yang menjadi wewenang Mahkamah Konstitusi (vide: UUD 1945 Amandemen ke-3 Pasal 24 C Ayat I Jo. UU No. 24 Tahun 2003 tentang Mahkamah Konstitusi, Pasal 10 ayat I huruf a);

2. Hak Uji Materiil terhadap peraturan perundang-undangan yang tingkatannya lebih rendah atau di bawah Undang-Undang (seperti: Peraturan Pemerintah, Keputusan Presiden, Peraturan Dae-rah, dll.) terhadap peraturan perundang-undangan yang lebih tinggi, yang menjadi wewenang Mahkamah Agung (vide: UUD 1945 Amandemen ke-3 Pasal 24 Ayat 1 Jo. UU No. 14 tahun 1985 tentang Mahkamah Agung sebagaimana telah diubah dengan UU No. 5 tahun 2004 Pasal 31, Jo. Peraturan Mahkamah Agung/ PERMA No. 1 tahun 1993 sebagaimana telah diubah dengan PERMA No. 1 tahun 1999, terakhir dengan PERMA No. 1 tahun 2004). Menurut PER-MA No. I tahun 2004 pasal I ayat (1), yang dimaksud dengan hak uji materiil adalah "hak mahkamah agung untuk menilai materi muatan peraturan perundangundangan dibawah Un-dang- Undang terhadap peraturan perandang-undangan yang lebih tinggi Hak uji materiil.

\section{B. Sifat Putusan Mahkamah Agung dalam Hak Uji Materil}

Suripto (Setneg.go.id), menyatakan bahwa baik dalam kepustakaan maupun dalam praktek dikenal ada dua macam hak menguji, yaitu:

a. Hak menguji formal adalah wewenang untuk menilai suatu produk legislatif seperti undangundang, dalam proses pembuatannya melalui cara-cara sebagaimana telah ditentukan/ 
diatur dalam peraturan perundang-undangan yang berlaku atau tidak. Pengujian formal terkait dengan masalah prosedural dan berkenaan dengan legalitas kompetensi institusi yang mem-buatnya.

b. Hak menguji material adalah suatu wewenang untuk menyelidiki dan menilai isi apakah sua-tu peraturan perundang-undangan itu sesuai atau bertentangan dengan peraturan yang lebih tinggi derajatnya, serta apakah suatu kekuasaan tertentu (verordenende macht) berhak mengeluarkan suatu peraturan tertentu. Pengujian material berkaitan dengan kemungkinan pertentangan materi suatu peraturan dengan peraturan lain yang lebih tinggi ataupun menyangkut kekhususankekhususan yang dimiliki suatu aturan dibandingkan dengan nor-ma-norma yang berlaku umum.

Dalam kaitannya dengan pengujian formil (formele toestsing) atau procedural review dan pengujianmaterilatausubstantivereview(materiele toetsing), membawa konsekuensi terhadap jenis pembatalan suatu norma dan daya berlakunya suatu pembatalan. Dalam hal permohonan HUM beralasan karena peraturan perundang-undangan tersebut bertentangan dengan undang-undang atau peraturan perundang-undangan lebih tinggi, MA dalam putusannya menyatakan bah-wa peraturan perundang-undangan yang dimohonkan keberatan tersebut sebagai tidak sah dan tid-ak berlaku untuk umum, serta memerintahkan kepada instansi yang bersangkutan segera pencabu-tannya (Pasal 6 Ayat (2) Perma No. 1/2011) (Fachruddin, 2004: 242).

Menurut Imam Sobechi (jimlyschool.com), adapun lingkup judicial review/toetsingrecht di Indonesia, yakni:

a. Peraturan Perundang-undangan (regeling):

i) Menguji undang-undang terhadap UUD dilakukan oleh MK (constitutional review)

ii) Menguji peraturan perundang-undang di bawah undang-undang terhadap undang-undang oleh MA

b. Pengujiankeputusan(beschikking)dilakukan oleh Peradilan Tata Usaha Negara.
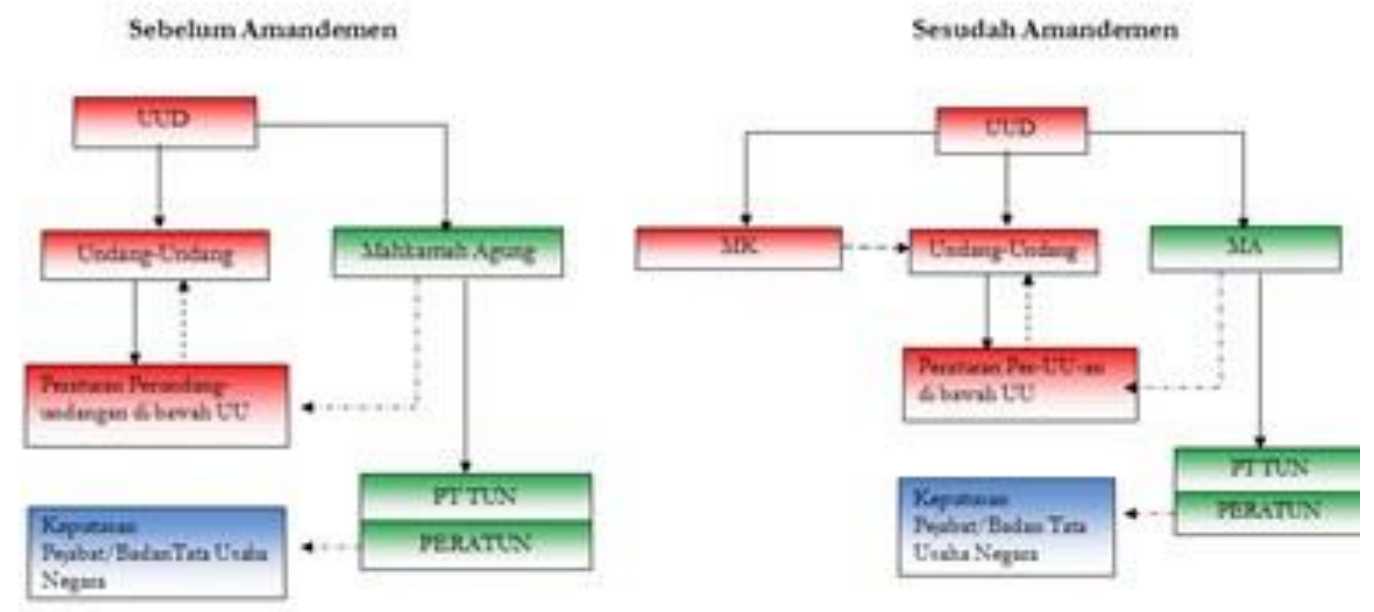

\section{Bagan 1.1 Kewenangan Judicial Review Sebelum dan Sesudah Amandeman UUD 1945}

Suripto menyatakan hak menguji secara materil terhadap undang-undang merupakan suatu kewenangan yang diberikan kepada badan peradilan untuk menguji apakah suatu peraturan tidak bertentangan dengan peraturan yang lebih tinggi. Kewenangan ini diberikan kepada Mahkamah Agung agar peraturan yang dibuat oleh lembaga legislatif dan eksekutif dapat diuji apakah sesuai atau tidak dengan peraturan yang lebih tinggi. Kewenangan Mahkamah Agung dalam hak menguji materil ter-hadap peraturan perundangundangan dibatasi hanya terhadap peraturanperaturan di bawah undang-undang. Sedangkan menurut Harun Al Rasid, hak menguji formal ialah mengenai prosedur pembuatan UU dan hak menguji material ialah mengenai kewenangan pembuat UU dan apakah isinya tidak bertentangan dengan yang lebih tinggi (Fatmawati, 2005: 94).

Konsekuensi dari pengujian secara formal adalah keseluruhan isi UU menjadi tidak memiliki 
kekuatan mengikat secara hukum, sedangkan uji materil hanya beberapa ketentuan sepeti pasal, ayat atau huruf. Menurut Jimly Asshidiqqie, pengertian yang dapat dikembangakan dalam rangka pemahaman terhadap konsepsi pengujian formil itu bersifat kompleks. Secara umum, kriteria yang dapat dipakai untuk menilai konstitusionalitas suatu UU dari segi formalnya (formele toetsing) adalah sejauh mana UU itu ditetapkan dalam bentuk yang tepat (appopriate form), oleh intitusi yang tepat (appropriate institution), dan menurut prosedur yang tepat (appropriate procedur) (Asshiddiqie (3), 2006: 63-64).

Jika dijabarkan dari ketiga kriteria ini, pengujian formil ini dapat mencakup:

a) Pengujian atas pelaksanaan tata cara atau prosedur pembentukan UU, baik dalam pembahasan maupun dalam pengambilan keputusan atas rancangan suatu UU menjadi UU.

b) Pengujian atas bentuk, format, atau struktur UU.

c) Pengujian yang berkenaan dengan keberwenangaan lembaga yang mengambil keputusan dalam proses pembentukan UU; dan Pengujian atas hal-hal lain yang tidak termasuk pengujian materil.

Dalam kaitannya dengan pengujian formil (formele toestsing) atau procedural review dan pengujian materil atau substantive review (materiele toetsing), membawa konsekuensi terhadap jenis pembatalan suatu norma dan daya berlakunya suatu pembatalan. Dalam hal permohonan HUM beralasan karena peraturan perundang-undangan tersebut bertentangan dengan undang-undang atau peraturan perundang-undangan lebih tinggi, MA dalam putusannya menyatakan bahwa peraturan pe-rundang-undangan yang dimohonkan keberatan tersebut sebagai tidak sah dan tidak berlaku untuk umum, serta memerintahkan kepada instansi yang bersangkutan segera pencabutannya (Pasal 6 Ayat (2) Perma No. 1/2011). Bukankah istilah "Tidak sah" mengacu kepada makna retroaktif, sedangkan batal mengacu konsep prospektif, atau dengan kata lain jika "tidak sah" berarti dianggap tidak pernah ada peratuan perundang-undangan itu (ex tunc). Sehubungan dengan hal tersebut, Bagir Manan menggunakan istilah "batal" dalam konteks putusan yang "prospektif” atau bersifat ex nunc atau pro future yaitu putusan yang berlaku ke depan. Dijelaskan: "peraturan perundang- undangan atau per-buatan administrasi Negara dipandang sebagai suatu yang sah sampai saat diinyatakan batal (dibatal-kan). Istilah "tidak sah" digunakan dalam konteks putusan "retroaktif" atau bersifat "ex tunc"; dengan kata lain putusan semacam ini menganggap peraturan perundangundangan atau perbuatan administasi tidak pernah ada. Putusan ini bersifat deklaratur, bukan konstitutif (Fachruddin, 2004: 242).

\section{Analisis Hukum Putusan Hak Uji Materil Nomor 20 P/HUM/2017}

Dalam objek permohonan keberatan Hak Uji Materiil Pemohon adalah Peraturan Dewan Per-wakilan Daerah Republik Indonesia Nomor 1 Tahun 2017 tanggal 21 Februari 2017 Tentang Tata Ter-tib. Sebagaimana yang menjadi kewenangan Mahkamah Agung untuk menguji Permohonan Keberatan Hak Uji Materiil didasarkan pada ketentuan Pasal 24A UndangUndang Dasar Tahun 1945, Pasal 20 Ayat (2) huruf b Undang-Undang Nomor 48 Tahun 2009 tentang Kekuasaan Kehakiman, dan Pasal 31A Undang-Undang Nomor 3 tahun 2009 tentang Perubahan Kedua atas Undang-Undang Nomor 14 Tahun 1985 tentang Mahkamah Agung berwenang menguji peraturan perundang-undangan di bawah undang-undang terhadap peraturan perundangundangan yang lebih tinggi. Maka, mengenai jenis dan hierarki peraturan perundang- undangan, selain diatur di dalam ketentuan Pasal 7 Ayat (1) Undang-Undang Nomor 12 Tahun 2011 tentang Pembentukan Peraturan Perundang-undangan, juga mencakup peraturan yang ditetapkan antara lain oleh DPD (vide Pasal 8 Ayat (1) UndangUndang Nomor 12 Ta-hun 2011 menyebutkan bahwa "Jenis Peraturan Perundang-Undangan Selain sebagaimana dimaksud Pasal 7 Ayat (1) mencakup Peraturan yang ditetapkan oleh Majelis Permusyawaratan Rakyat, Dewan Perwakilan Rakyat, Dewan Perwakilan Daerah, dan lain sebagainya.

Meskipun Pasal 8 ayat (1) Undang-Undang Nomor 12 Tahun 2011 tidak menyebutkan secara eksplisit bentuk-bentuk formal peraturan dimaksud, namun Mahkamah Agung berpendapat bahwa objek Hak Uji Materiil a quo secara materiil termasuk dalam katagori peraturan perundangundangan, dengan pertimbangan: Keberadaan Objek Hak Uji Materiil pembentukkannya berdasarkan perintah peraturan perundangundangan yang lebih tinggi yang merupakan 
regulasi yang dibentuk sesuai kewenangan yang diperoleh secara atribusi yang kemudian mendelegasikan kewenangan kepada DPD untuk mengaturnya lebih lanjut, hal tersebut didasarkan pada ketentuan Peraturan Perundang-undangan sebagai berikut:

a) Pasal 260 Ayat (7) Undang-Undang Nomor 17 Tahun 2014 tentang Majelis Permusyawaratan Rakyat, Dewan Perwakilan Rakyat, Dewan Perwakilan Daerah, dan Dewan Perwakilan Rakyat Daerah, menentukan bahwa "Ketentuan lebih lanjut mengenai tata cara pemilihan Pimpinan DPD diatur dalam peraturan DPD tentang tata tertib";

b) Pasal 261 Ayat (2) Undang-Undang Nomor 17 Tahun 2014 tentang Majelis Permusyawaratan Rakyat, Dewan Perwakilan Rakyat, Dewan Perwakilan Daerah, dan Dewan Perwakilan Rakyat Daerah, menentukan bahwa "Ketentuan lebih lanjut mengenai tata cara pelaksanaan tugas pimpinan sebagaimana dimaksud pada Ayat (1) diatur dalam peraturan DPD tentang tata ter-tib."'; Dengan demikian, Objek Hak Uji Materiil berupa Peraturan Dewan Perwakilan Daerah Republik Indonesia Nomor 1 Tahun 2017 tanggal 21 Februari 2017 Tentang Tata Tertib, merupakan peraturan perundangundangan sebagaimana dimaksud dalam ketentuan Pasal 8 Ayat (1) Undang-Undang Nomor 12 Tahun 2011 tentang Pembentukan Peraturan Perundang-undangan, sehingga memenuhi syarat sebagai objek Hak Uji Materiil yang menjadi wewenang Mahkamah Agung untuk mengujinya;

c) Pemohon sebagai individual anggota DPD yang melekat didalamnya jabatan sebagai anggota DPD-RI telah dirugikan dengan berlakunya ketentuan Pasal 47 Ayat (2) dan Pasal 323 Pera-turan Dewan Perwakilan Daerah Republik Indonesia Nomor 1 Tahun 2017 tanggal 21 Februari 2017 Tentang Tata Tertib dikarenakan peraturan tersebut telah menimbulkan ketidakpastian hukum kepada Para Pemohon dimana setiap keputusan politik yang diambil tidak lagi ber-dasarkan ketentuan hukum dan peraturan perundangundangan yaitu terhadap Undang-Undang Nomor 12 Tahun 2011. Para Pemohon sebagai anggota DPD tidak lagi memiliki pegangan dan rambu-rambu hukum dalam setiap pengambilan keputusan politik khususnya mengenai masa jabatan Pimpinan DPD. Padahal, sebelumnya Pimpinan DPD sudah ditentukan untuk masa jabatan 5 tahun, namun hal tersebut ditabrak dan dilanggar dengan menjadikan menjadi 2,5 ta-hun dan inipun diberlakukan secara surut. Hal demikian jelas telah merugikan Para Pemohon, karena bertentangan dengan Undang-Undang Nomor 12 Tahun 2011.

d) Para Pemohon juga telah dirugikan hak memilihnya ketika memilih Pimpinan DPD untuk masa jabatan 5 tahun, yang kemudian dipotong menjadi 2 tahun dan 6 bulan, Para Pemohon yang te-lah menggunakan hak pilihnya pada pemilihan Pimpinan DPD 2014. Bagaimanapun pada saat menggunakan hak pilihnya untuk memilih pimpinan adalah untuk 5 tahun sesuai masa keanggotaan DPD 2014-2019.

e) Berangkat dari ketentuan pimpinan DPD dipilih dari dan oleh anggota DPD, artinya bahwa da-lam proses pemilihan pimpinan DPD pasti melibatkan seluruh anggota DPD dalam hal ini Para Pemohon. Ketika terjadi kontestasi pemilihan pimpinan DPD, seolaholah anggota DPD tidak terpengaruh, namun demikian mengingat ketentuan pimpinan dipilih dari dan oleh anggota, maka anggota otomatis terpengaruh dan dapat ditarik-tarik dalam proses pemilihan Pimpinan.

Perdebatan internal berkaitan dengan Peraturan Dewan Perwakilan Daerah Republik Indonesia Nomor 1 Tahun 2017 tanggal 21 Februari 2017 Tentang Tata Tertib, dimana perdebatan dimaksud adalah terjadi akibat dari adanya rumusan ketentuan masa jabatan pimpinan 2 (dua) tahun 6 (enam) bulan dan ketentuan pemberlakuan surut Peraturan DPD tersebut. Para Pemohon terlibat secara lang-sung dan merupakan pihak yang tidak menyetujui rumusan tersebut, oleh karena menurut Para Pemo-hon rumusan Peraturan Dewan Perwakilan Daerah Republik Indonesia Nomor 1 Tahun 2017 tanggal 21 Februari 2017 Tentang Tata Tertib bertentangan dengan peraturan perundang-undangan, serta mengesampingkan apa yang telah Mahkamah Agung kemukakan di dalam pandangannya (Pandangan MA, Jakarta 16 Desember 2016) 
setelah sebelumnya diminta oleh Panitia Khusus Tatib DPD;

Peraturan Dewan Perwakilan Daerah Republik Indonesia Nomor 1 Tahun 2017 tanggal 21 Februari 2017 Tentang Tata Tertib tersebut akhirnya ditetapkan atas kehendak Paripurna yang diagen-dakan untuk itu, pada hari selasa, tanggal 21 Februari 2017. Atas dasar telah ditetapkan melalui parip-urna tersebut, Peraturan Dewan Perwakilan Daerah Republik Indonesia Nomor 1 Tahun 2017 tanggal 21 Februari 2017 Tentang Tata Tertib, ketentuan terkait masa jabatan Pimpinan sebagaimana diatur dalam Pasal 47 Ayat (2) dan Pasal 323 akan segera diberlakukan, dan kemudian terhadap Pimpinan DPD yang seharusnya memiliki masa jabatan hingga 2019 akan dipotong masa jabatannya pada akhir Maret 2017. DPD kemudian akan mengagendakan pemilihan pimpinan DPD baru dengan masa jabatan April 2017-2019;

\section{Pendapat Hukum Mahkamah Agung}

Berdasarkan dalil-dalil dalam Permohonan Para Pemohon dan Jawaban Termohon beserta bukti-bukti yang diajukan oleh Para Pemohon dan Termohon, Mahkamah Agung berpendapat bahwa alasan keberatan Para Pemohon dapat dibenarkan, dengan pertimbangan:

a) Mahkamah Agung berwenang melakukan pengujian terhadap peraturan di bawah undang-undang yang dimuat dalam Pasal 24 A Ayat (1) UUD 1945, Pasal 11 Ayat (2) huruf b Undang-Undang Nomor 4 Tahun 2004 tentang Kekuasaan Kehakiman, Pasal 31 Ayat (2) Undang-Undang Nomor 5 Tahun 2004 tentang Perubahan Undang-Undang Nomor 14 Tahun 1985 tentang Mahkamah Agung, menentukan standar ukuran suatu peraturan dibawah undang-undang dapat dibatalkan, atas alasan:

1). Karena bertentangan dengan Peraturan Perundang-undangan yang lebih tinggi (aspek materiil) atau;

2). Pembentukannya tidak memenuhi ketentuan yang berlaku (aspek formil).

b) Secara subtansi objek HUM a quo, secara yuridis materiil terdapat pelanggaran yaitu:

1) Terkait dengan masa jabatan Pimpinan Dewan Perwakilan Daerah Republik Indonesia telah ditetapkan menjadi 2 (dua) tahun 6 (enam) bulan sebagaimana diatur oleh Pasal 47 Ayat (2) Peraturan Dewan Perwakilan Daerah Republik Indonesia Nomor 1 Tahun 2017 tanggal 21 Februari 2017 Tentang Tata Tertib;

2) Dalam masa Jabatan pimpinan MPR dan DPR secara eksplisit diatur pada Pasal 24 Jo Pasal 8 Ayat (2) Peraturan MPR RI Nomor 1 Tahun 2014 tentang Tata Tertib yaitu masa jabatan Pimpinan MPR sama dengan masa jabatan keanggotaan MPR adalah 5 (lima) tahun. Sedangkan untuk Pimpinan DPR diatur pada Pasal 27 Peraturan DPR RI Nomor 1 Tahun 2014 tentang Ta-ta Tertib, yaitu masa Jabatan Pimpinan DPR sama dengan masa keanggotaan DPR adalah 5 (lima) tahun. Dipandang dari karakteristiknya, DPD berada di dalam satu rumpun dengan MPR dan DPR, yaitu sebagai Lembaga Perwakilan, sebagaimana diatur pada Undang-Undang No-mor 17 Tahun 2014.

3) Bahwa pada hakikatnya pengabdian setiap negarawan, termasuk anggota DPD, pada tingkat tertinggi adalah kepada bangsa dan negara. Anggota DPD yang terpilih menjadi pimpinan DPD, memimpin lembaga yang tugas utamanya adalah menyerap dan mengartikulasikan as-pirasi daerah, sehingga dengan jabatan tersebut saluran aspirasi dari daerah dapat terwakili dalam proses pengambilan keputusan nasional. Namun demikian, tidak seperti MPR/DPR, DPD tidak dicalonkan melalui Partai Politik. Oleh sebab itu, tidak terdapat pengelompokan kekuatan politik didalamnya. Menjadi pimpinan lembaga bukanlah untuk mewakili kelompok tertentu, melainkan untuk institusi DPD itu sendiri, sehingga tidak sepatutnya apabila jabatan pimpinan DPD tersebut dipergilirkan yang dapat menimbulkan kesan berbagi kekuasaan;

4) Bahwa Lampiran II Huruf C5, nomor 155 Ketentuan Peralihan UndangUndang Nomor 12 Tahun 2011, tentang Pembentukan Peraturan Perundangundangan menyatakan, pada da-sarnya mulai berlakunya Peraturan Perundang- 
undangan tidak dapat ditentukan lebih awal da-ripada saat pengundangannya, dengan demikian Lampiran II Huruf C5, nomor 155 Ketentuan Peralihan Undang-Undang Nomor 12 Tahun 2011 tersebut menegaskan tentang larangan asas non retroaktif. Hal tersebut selaras dengan kaidah normatif yang termuat di dalam Pasal 28I Ayat (1) UUD 1945, yang secara tegas menyatakan bahwa hak untuk tidak dituntut atas.

Berdasarkan pertimbangan dan dalil-dalil yang ada, maka Mahkamah Agung, memutuskan: Mengabulkan permohonan keberatan hak uji materiil dari Pemohon, dengan menyatakan Peraturan Dewan Perwakilan Daerah Republik Indonesia Nomor 1 Tahun 2017 tanggal 21 Februari 2017 tentang Tata Tertib bertentangan dengan peraturan perundang-undangan yang lebih tinggi, yaitu Undang-Undang Nomor 12 Tahun 2011 tentang Pembentukan Peraturan PerundangUndangan dan karenanya tidak sah dan tidak mempunyai kekuatan hukum mengikat; disamping itu juga memerintahkan kepada Pimpinan Dewan Perwakilan Daerah untuk mencabut Peraturan Dewan Perwakilan Daerah Republik Indonesia Nomor 1 Tahun 2017 tanggal 21 Februari 2017 tentang Tata Tertib.

\section{Implikasi Legalitas Pimpinan Dewan Perwakilan Daerah}

Proses pemilihan pimpinan DPD yang dilaksanakan pada tanggal 4 April 2017 dinilai memiliki cacat hukum. Hal ini karena pelaksanaan pemilihan tersebut tidak lagi memiliki dasar hukum karena peraturan yang dijadikan dasar pemilihan itu sudah dibatalkan oleh MA melalui Putusan Nomor 38P/HUM/2017 dan Nomor 20P/HUM/2017. Dalam putusan tersebut MA membatalkan Peraturan DPD Nomor 1 Tahun 2016 dan Peraturan DPD Nomor 1 Tahun 2017 karena bertentangan dengan UU Nomor 7 Tahun 2014 dan UU Nomor 12 Tahun 2011.

Pembatalan kedua peraturan DPD tersebut menyebabkan aturan itu kehilangan legitimasi dan tidak mempunyai kekuatan hukum mengikat. Sehingga kedua peraturan DPD tersebut tidak bisa di-jadikan rujukan/pijakan untuk melakukan tindakan hukum, dalam hal ini melakukan pemilihan pim-pinan DPD yang "baru". Pemilihan pimpinan DPD versi jabatan 2,5 tahun sejatinya tidak boleh ada karena MA membatalkan dasar hukumnya. Pembatalan itu juga berimplikasi pada berlakunya Pera-turan Tata Tertib DPD Nomor 1 tahun 2014 yang mengatur bahwa masa jabatan pimpinan DPD adalah selama 5 tahun. Lebih-lebih, dalam pertimbangan hukumnya, pembatalan Peraturan Tatib DPD dil-akukan MA karena alasan melanggar asas non-retroaktif.

Mengenai masa jabatan ini, majelis hakim uji materi MA dalam pertimbangan putusan No.20P/HUM/2017, menyatakan bahwa DPD satu rumpun dengan MPR dan DPR. Oleh karena itu, masa jabatan pimpinan DPD ditetapkan sama dengan masa jabatan pimpinan lembaga tinggi lainnya. Majelis juga mengingatkan bahwa pengabdian tertinggi anggota DPD seharusnya kepada bangsa dan negara, bukan pada kelompok tertentu. Dengan demikian, jika tindakan pemilihan pimpinan "baru" versi jabatan 2,5 tahun itu tetap dilakukan berdasarkan peraturan yang telah dibatalkan, maka tindakan tersebut dapat disebut sebagai tindakan ilegal atau tindakan yang berlawanan dengan hukum. Konsek-uensinya, tindakan tersebut menjadi tidak sah secara hukum dan dapat dinyatakan batal demi hukum. Pertama, karena melanggar Tatib Nomor 1 tahun 2014 dan kedua, melawan putusan MA.

Selain cacat substansi, ketidakabsahan proses pemilihan itu menjadi semakin nyata manakala memperhatikan fakta bahwa agenda rapat pemilihan itu diputuskan dalam rapat yang tidak quorum. Dari sisi prosedur, agenda pemilihan itu jelas mengandung cacat prosedural. Oleh karena proses pem-ilihan pimpinan DPD tersebut merupakan tindakan yang tidak sah karena berlawanan dengan hukum, maka pelantikan terhadap pimpinan DPD "baru" itupun menjadi tidak sah. Pelanggaran hukum lainnya yang lahir dari tindakan yang sudah keliru sejak awal adalah kehadiran Wakil Ketua MA un-tuk memandu proses pengucapan sumpah jabatan pimpinan DPD.

Sebagaimana telah disinggung sebelumnya, tindakan Wakil Ketua MA ini jelas bertentangan dengan ketentuan Pasal 260 ayat (6) UU MD3. Pasal itu dengan tegas mengatur bahwa hanya Ketua MA yang dapat melakukan pelantikan (pengucapan sumbah jabatan) pimpinan DPD. Ketentuan Pasal 260 itu sejalan dengan Pasal 253 Ayat (1) UU MD3 bahwa Ketua MA melantik anggota DPD terpilih. Jadi, hanya Ketua MA yang berhak untuk melakukan pelantikan, bukan yang 
lain. Ketaatan MA ter-hadap aturan ini terlihat ketika terjadi pergantian Ketua DPD dari Irman Gusman (tertangkap tangan oleh KPK) kepada M. Shaleh. Ketua DPD terpilih, M. Shaleh, tak langsung dilantik oleh Ketua MA. Pada waktu itu, pelantikan M. Shaleh sempat tertunda dan tidak ada perwakilan dari MA. Akhirnya, Ketua MA datang dan melakukan pelantikan Ketua DPD yang baru menggantikan Irman Gusman. Per-istiwa ini membuktikan bahwa MA taat pada prosedur yang ditetapkan dalam Pasal 260 ayat (6). Akan tetapi, ketaatan itu dilanggar oleh MA sendiri ketika Wakil Ketua MA, Suwardi, melakukan pelantikan atas pimpinan DPD yang "baru".

Tidak jelas apakah kedatangan Wakil Ketua MA itu atas kehendak pribadi sendiri atau penugasan khusus dari Ketua MA. Dengan demikian, dapat diartikan bahwa tindakan tersebut selain me-langgar hukum juga bertentangan dengan asas tertib administrasi, salah satu asas umum pemerintahan yang baik yang harus dirujuk oleh penyelenggara negara. Azas itu menyatakan bahwa hanya pejabat yang berwenanglah yang dapat melakukan suatu tindakan administratif. Kewenangan administratif melakukan pelantikan itu diperoleh secara atributif melalui perintah UU MD3. Sehingga secara ekslu-sif, tindakan itu hanya dapat dilakukan oleh pejabat yang diperintah oleh UU (Ketua MA), kecuali ditentukan lain oleh UU.

Prinsip itu dapat saja disimpangi, jika memang terjadi keadaan darurat atau keadaan yang luar biasa yang membuat pejabat yang bersangkutan tidak dapat menjalankan tugasnya, misalnya berhalangan tetap atau terjadi kevakuman posisi Ketua MA. Selama masih ada Ketua MA, maka tin-dakan pelantikan itu haruslah dilakukan oleh yang bersangkutan. Sebab UU tidak membuka kemung-kinan lainnya dan praktik ketatanegaraan selama ini menunjukkan ketaatan atas prosedur itu. Oleh sebab itu, untuk tetap menghormati supremasi hukum di Republik Indonesia, Ketua MA harus mem-batalkan tindakan pelantikan terhadap pimpinan DPD yang telah dilakukan oleh bawahannya. Tinda-kan itu harus dikoreksi oleh Ketua MA, demi menjaga marwah lembaga peradilan tertinggi di republik ini.

\section{KESIMPULAN}

Konsep Hak Uji Materiil (disingkat HUM) pada prinsipnya adalah suatu hak atau kewenangan yang dimiliki oleh lembaga Yudikatif untuk melakukan pengujian mengenai sah atau tidaknya suatu peraturan perundang-undangan terhadap peraturan perundang-undangan yang tingkatnya lebih tinggi. Hak uji materiil di Indonesia dapat digolongkan menjadi dua macam, yaitu: Hak uji materiil atas Undang-Undang terhadap Undang-Undang Dasar, yang menjadi wewenang Mahkamah Konstitusi dan Hak Uji Materiil terhadap peraturan perundang-undangan yang tingkatannya lebih rendah atau di bawah Undang-Undang menjadi wewenang Mahkamah Agung. Sifat Putusan Hak Uji Materil Mahkamah Agung, yakni bersifat ex nunc atau pro future yaitu putusan yang berlaku ke depan. Suatu peraturan perundang-undangan atau perbuatan administrasi negara dipandang sebagai suatu yang sah sampai saat diinyatakan batal (dibatalkan). Adapun batal mengacu konsep prospektif, atau dengan ka-ta lain jika "tidak sah" berarti dianggap tidak pernah ada Peratuan perundang-undangan itu (ex tunc).

Mahkamah Agung dalam putusannya menyatakan bahwa peraturan perundangundangan yang dimohonkan untuk diuji materi tersebut sebagai (1) peraturan yang tidak sah atau (2) tidak berlaku un-tuk umum serta (3) memerintahkan pada instansi yang bersangkutan untuk mencabutnya. Terlihat da-lam ketentuan Pasal 6 tersebut bahwa inti dari putusan MA adalah menyatakan dengan tegas bahwa suatu peraturan tidak sah atau tidak memiliki kekuatan hukum mengikat (tidak berlaku). Perihal perintah kepada instansi yang bersangkutan untuk mencabut peraturan yang sudah dibatalkan dalam tenggat waktu 90 hari, merupakan konsekuensi logis ketika sebuah peraturan telah dibatalkan oleh MA. Ketentuan ini merupakan bentuk penegasan tindakan administratif yang harus diambil oleh Ba-dan/pejabat yang mengeluarkan peraturan tersebut. Pencabutan itu harus dilakukan segera, tanpa tin-dakan administratif pencabutan itu pun, peraturan yang sudah dinyatakan tidak memiliki kekuatan hukum mengikat oleh MA, tidak lagi dapat diberlakukan. Implikasi Pengangkatan Pimpinan Dewan Perwakilan Daerah Pasca Putusan Hak Uji Materil Mahkamah Agung Nomor 20P/HUM/2017, bahwa secara hukum tidak sah dan tidak mempunyai kekuatan hukum mengikat; disamping itu juga memerintahkan kepada Pimpinan Dewan Perwakilan Daerah untuk mencabut Peraturan Dewan Perwakilan Daerah Republik Indonesia Nomor 1 Tahun 2017 tentang Tata Tertib. 


\section{SARAN}

Dalam ketentuan Hak Uji Matertil di Mahkamah Agung, bahwa putusan Mahkamah Agung sama halnya dengan putusan Mahkamah Konstitusi. Dimana putusan tersebut bersifat final, mengikat dan berlaku secara serta merta. Disamping itu, putusan Mahkamah Agung yang memerintahkan kepada pejabat atau badan yang membuat peraturan itu untuk mencabut peraturan tersebut dan apabila dalam tenggat waktu 90 hari putusan itu tidak dicabut, maka putusan tersebut tidak mempunyai kekuatan hukum mengikat. Semestinya para Pemohon harus taat hukum dengan mematuhi putusan Hak Uji Ma-teril Mahkamah Agung karena berkorelasi sejak putusan itu dibacakan tanpa menunggu tenggat waktu 90 hari, hal ini tidak lain untuk memberikan jaminan kepastian hukum. Tanpa tindakan administratif pencabutan itu pun, putusan tersebut mempunyai konsekuensi hukum terhadap peraturan yang telah dibatalkan dan dinyatakan tidak memiliki kekuatan hukum mengikat oleh MA. 


\section{DAFTAR KEPUSTAKAAN}

\section{Buku:}

Asshiddiqie, Jimly, (2) Konstitusi dan Konstitusionalisme Indonesia, Edisi Revisi, Jakarta: Konstitusi Press, 2005.

Asshiddiqie, Jimly (3), Hukum Acara Pengujian Undang-Undang, Jakarta: Konstitusi Pers, 2006Asshiddiqie, Jimly (4), Sengketa Kewenangan Antar Lembaga Negara. Jakarta: Konstitusi Press, 2006.

Asshiddiqie, Jimly, (1) Menuju Negara Hukum Yang Demokratis, Jakarta: PT.Bhuana Ilmu Populer, 2009.

Fachruddin, Irfan. Pengawasan Peradilan Administrasi terhadap tindakan Pemerintah, Bandung: PT. Alumni, 2004.

Fatmawati, Hak Menguji (Toetsingrecht) yang dimiliki Hakim dalam sistem Hukum Indonesia, Jakarta: Rajagrafindo Persada, 2005.

Harahap, M. Yahya, Beberapa Tinjauan Mengenai Sistem Peradilan dan Penyelesaian Sengketa, Ja-karta : Citra Aditya Bhakti, 1997.

Pompe, Sebastiaan, Runtuhnya Institusi Mahkamah Agung, Lembaga Kajian dan Advokasi untuk In-dependensi Peradilan, Jakarta. Penerjemah Noor Cholis, 2012.

Sulaiman King Faisal, 2017, Teori Peraturan Perundang-Undangan dan Aspek Pengujiannya, Yog-yakarta, Thafa Media, 2017.

Utrecht, Pengantar Hukum Administrasi Negara Indonesia, Jakarta: Ichtiar, 1962.

\section{Peraturan Perundang-Undangan:}

Undang-Undang Dasar Negara Republik Indonesia Tahun 1945 Hasil Amandemen

Undang-Undang No. 12 Tahun 2011 tentang Pembentukan Peraturan PerundangUndangan (Lembaran Negara Republik Indonesia Tahun 2011 Nomor 82, Tambahan Lembaran Negara Republik Indonesia Nomor 5234)

Undang-Undang No.17 Tahun 2014 tentang MPR, DPR, DPD, DPRD (Lembaran Negara Republik In-donesia Tahun 2014 nomor
182, tambahan Lembaran Negara Republik Indonesia Nomor 5568)

Peraturan Mahkamah Agung RI Nomor 01 Tahun 2011 tentang Hak Uji Materiil

Putusan Mahkamah Agung RI Nomor 20P/ HUM/2017

\section{Sumber Lain:}

Asshiddiqie, Jimly, Negara Hukum Indonesia, Makalah, dalam rangka Pelantikan Dewan Pimpinan Pusat Ikatan Alumni Universitas Jayabaya, di Jakarta, 2010.

Jazuli, Ahmad, Pembangunan Pertahanan dan Keamanan Demi Penegakan Hukum di Indonesia: Kewibawaan Suatu Negara, Jurnal Penelitian Hukum De Jure, Vol. 16 No. 2, Juni 2016.

http://politik.rmol.co/read/2017/04/06/286700/ Pelantikan-Pimpinan-DPD,-KelemahanSistem-Uji-Materil-MA-Dan-DilemaNegara-Kita-

http://www.jimlyschool.com/read/news/338/hakuji-materiil-di-mahkamah-agung/

Mahfud, Moh MD, "Konstitusi Negara”. Makalah disampaikan dalam Acara Orientasi Anggota DPR RI Fraksi PDI Perjuangan 2009-2014, Jakarta. 2009.

Schroeder, Richard C, Garis Besar Pemerinhan Amerika Serikat, Kantor Program Informasi Internasional Departemen Luar Negeri Amerika Serikat, 2000

Sihombing, Eka NAM, Menyoal Ketentuan Usul Pindah Pegawai Negeri Sipil Di Lingkungan Pemerintah Daerah Kabupaten Nias Barat, Jurnal Penelitian Hukum DE JURE, Vol. 16 No. 1, Maret 2016 : 95 - 104

Suripto, Kepala Pusat Pendidikan dan Pelatihan Sekretariat Negara Republik Indonesia, Wewenang Mahkamah Konstitusi Menguji Undang-Undang (Judicial Review), Kamis, 21 Juni 2007, http://www.setneg.go.id/index. php. 